\title{
PENGARUH PENAMBAHAN ABU AMPAS TEBU TERHADAP SIFAT KIMIA AIR RENDAMAN (pH, TDS DAN KESADAHAN TOTAL) DAN SIFAT KUAT TEKAN MORTAR SEMEN PCC PADA PERENDAMAN AIR LAUT
}

\section{THE EFFECT OF ADDITIONAL OF AMPAS SALT TOWARDS THE CHEMICAL PROPERTIES OF WATER (pH, TDS AND TOTAL ESSENCE) AND THE STRONG PRESSURE OF MORTAR CEMENT PCC ON SEA WATER SEA}

\author{
Yulizar Yusuf*, Hermansyah Aziz, Pepi Rahmi Sari Jaslia \\ ${ }^{1}$ Jurusan Kimia, FMIPA, Universitas Andalas Padang \\ email: yulizaryusuf59@gmail.com
}

\begin{abstract}
Ashes of bagasse are waste that has several uses. Ash toe bagasse is known to have a silica content of about $70 \%$ and is chemically quite feasible as a pozolan material. Research on the effect of adding bagasse asphalt to the chemical properties of immersion water $(\mathrm{pH}$, TDS and total hardness) and the compressive strength of PCC cement mortar on sea water immersion have been conducted. Ashes of bagasse can be used as another alternative to reduce clinker usage and as waste utilization. The compressive strength study on mortar was done by mixing the ash of bagasse and PCC cement with a ratio of $0,2,4$ and $6 \%$, while the immersion water was chemically analyzed for the effect of $\mathrm{pH}$, TDS and total hardness. Based on the analysis with the addition of bagasse ash does not affect the compressive strength according to SNI 15-7064-2004 PCC cement. For aquamarine and marine aquedent immersion water, there is an increase in $\mathrm{pH}$ to soaking time. For TDS and total hardness tests for washed water the aquades had increased in variation in the composition of bagasse ash and duration of immersion. At sea water immersion TDS value and total hardness 3 days higher than 28 days.
\end{abstract}

Keywords: ash bagasse, compressive strength, sea water, PCC cement

\begin{abstract}
Abstrak
Abu ampas tebu merupakan limbah buangan yang memiliki beberapa kegunaan. Abu ampas tebu diketahui memiliki kandungan silika sekitar $70 \%$ dan secara kimiawi cukup layak sebagai bahan pozolan. Penelitian tentang pengaruh penambahan abu ampas tebu terhadap sifat kimia air rendaman ( $\mathrm{pH}$, TDS dan kesadahan total) dan sifat kuat tekan mortar semen PCC pada perendaman air laut telah dilakukan. Abu ampas tebu dapat digunakan sebagai alternatif lain untuk mengurangi penggunaan klinker dan sebagai pemanfaatan limbah. Penelitian kuat tekan pada mortar dilakukan dengan mencampurkan abu ampas tebu dan semen PCC dengan perbandingan 0, 2, 4 dan 6\%, sedangkan air rendaman dianalisis secara kimia tentang pengaruh $\mathrm{pH}$, TDS dan kesadahan totalnya. Berdasarkan hasil analisis dengan penambahan abu ampas tebu tidak mempengaruhi kuat tekan menurut SNI 15-7064-2004 semen PCC. Untuk air rendaman mortar akuades dan air laut, terjadi kenaikan pH terhadap waktu perendaman. Untuk uji TDS dan kesadahan total untuk air rendaman akuades mengalami kenaikan pada variasi komposisi abu ampas tebu dan lamanya perendaman. Pada perendaman air laut nilai TDS dan kesadahan total 3 hari lebih tinggi daripada 28 hari.
\end{abstract}

Kata kunci: abu ampas tebu, kuat tekan, air laut, semen PCC 


\section{PENDAHULUAN}

Mortar adalah campuran semen, pasir dan air dengan persentase yang berbeda. Perbandingan semen, pasir dan air yang sesuai untuk mortar yang memenuhi syarat adalah 1: 2,75: 0,5. Sebagai bahan pengikat, mortar harus mempunyai konsistensi/kekentalan standar. Konsistensi mortar ini nantinya akan berguna dalam menentukan kekuatan mortar yang menjadi spesi ataupun plesteran dinding sehingga diharapkan mortar tidak hancur akibat menahan daya tekan beban yang bekerja padanya (Nugraha, 2003).

Kegunaan plester adalah melapisi pasangan batu bata, batu kali maupun batu cetak (batako) agar permukaannya tidak mudah rusak, kelihatan rapi dan bersih. Pekerjaan memplester juga dilakukan pada pasangan pondasi, pasangan tembok dinding rumah, lantai batu bata, lisplang beton, dan sebagainya (Mulyati, Sri, Dahyunir \& Elvis, -).

Meskipun teknologi mortar telah terbukti kemampuannya, namun karena tuntutan konstruksi terhadap kekuatan, kelenturan dan keawetan maka teknologi ini dapat ditingkatkan efektifitas kinerjanya dengan pendekatan: perbaikan atas mutu mortar dan penggabungan teknologi pembuatan berbagai komposit.

Selama ini mortar masih menggunakan semen Portland dan kapur sebagai bahan ikat utama yang harganya cukup mahal. Oleh karena itu diperlukan alternative bahan baku lain yang memiliki harga murah dan merupakan limbah yang dapat meningkatkan sifat mekanis mortar. Bahan baku alternatef digunakan pada penelitian ini adalah abu ampas tebu (bagasse ash). Beberapa penelitian terdahulu telah melakukan kajian analisis pemanfaatan abu ampas tebu.

Indonesia sebagai Negara agraris memiliki kekayaan alam dari struktur perkebunan. Berbagai jenis perkebunan yang dapat menjadi komoditi eksport dapat ditemukan di Indonesia seperti perkebunan tebu, tembakau, karet, kelapa sawit, perkebunan buah-buahan dan lainnya. Diantara semua jenis perkebunan di Indonesia tersebut, perkebunan tebu merupakan sumber bahan baku untuk pembuatan gula (Margaretta, 2009).
Produksi gula tebu yang terus meningkat membawa dampak terhadap peningkatan ampas tebu dengan peningkatan yang besar. Ampas tebu yang merupakan limbah buangan ini belum dapat dimanfaatkan secara maksimal di Indonesia seperti negara lain. Di beberapa Negara ampas tebu memiliki beberapa kegunaan yang dimanfaatkan sebagai pembersih lantai, digunakan untuk menjaga kondisi tanah agar selalu siap pakai untuk pertanian, sebagai makanan unggas, dibuat plastik, dan dapat pula dibuat partikel board. Pada umumnya ampas tebu digunakan untuk bahan bakar untuk memanaskan boiler pada pabrik tebu. Dari hasil pembakaran tersebut menghasilkan abu ampas tebu yang juga dapat difungsikan sebagai pupuk (Mulyati, Sri, Dahyunir \& Elvis, -).

Pembakaran abu ampas tebu memiliki unsur yang bermanfaat untuk peningkatan kekuatan mortar, karena mempunyai sifat pozolan dan mengandung silika yang tinggi. Bila unsure ini dicampur dengan semen akan menghasilkan kekuatan yang lebih tinggi. Pemilihan abu ampas tebu sebagai bahan aditif yang memiliki kandungan $\mathrm{SiO} 2$ yang tinggi merupakan pengikat agregat yang baik (Margaretta, 2009).

Struktur yang dibangun pada lingkungan yang agresif, seperti air laut memerlukan perhatian yang sangat serius. Di lingkungan tersebut kekuatan struktur mortar akan mengalami penurunan akibat penetrasi ion klorida yang dikandung oleh air laut yang masuk kedalam beton. Hal ini berbahaya karena dapat mengakibatkan terjadinya pelapukan pada mortar yang secara langsung akan mengakibatkan melemahnya kekuatan struktur mortar tersebut.

Untuk mengurangi kerugian yang ditimbulkan akibat pengaruh ion klorida, sulfat pada mortar, seringkali digunakan beton dengan mutu tinggi. Hal ini dimaksudkan agar penetrasi air laut ke dalam mortar menjadi semakin sulit karena tingkat kepadatan mortar yang tinggi. Sehingga kekuatan tekan mortar yang berada dilingkungan yang agresif tidak mengalami perubahan. Sehingga mutu mortar pada lingkungan yang agresif seperti 
di daerah pinggir laut akan sesuai dengan yang diharapkan (Nugraha, 2003).

Berdasarkan penjelasan diatas, maka penulis mencoba melakukan penelitian terhadap penggunaan abu ampas tebu sebagai alternatif lain untuk mengurangi penggunaan klinker dan pemanfaatan limbah pertanian.

\section{METODE PENELITIAN}

\section{Alat dan bahan yang digunakan}

Peralatan gelas (buret $50 \mathrm{~mL}$, gelas piala $250 \mathrm{~mL}$, corong kaca masir, pipet gondok $25 \mathrm{~mL}$, Erlenmeyer $250 \mathrm{~mL}$ dan batang pengaduk), $\mathrm{pH}$ meter Ultra Basic, oven merk Carbolite, pompa vakum, neraca analitik merk Sartorius TE 2145, desikator, furnace merk Carbolite tipe RHF 1600, cawan penguap, alat pembuatan mortar (Automatic Mixer) dan cetakan (mould), serta alat pengukuran kuat tekan (Compresive Strenght). Semen PCC (produksi PT. Semen Padang), abu ampas tebu (diperoleh dari pabrik gula tebu di Nagari Tabeh Hiliran Gumanti Alahan Panjang, Kabupaten Solok), pasir Ottawa yang diimpor dari Kanada, larutan buffer $\mathrm{pH}$ 10, larutan EDTA 0,02M, indikator EBT, akuades dan air laut.

\section{Prosedur penelitian}

\section{Pembuatan sampel}

Abu ampas tebu diperoleh dari pabrik gula tebu di Nagari Tabeh Hiliran Gumanti, Alahan Panjang, kabupaten Solok, yang sudah menjadi abu. Untuk pembuatan mortar standar, maka dilakukan pencampuran bahan-bahan seperti pasir dan semen yang ditimbang sesuai dengan perbandingan yaitu 1:2,75 serta air 0,5. Kemudian bahan-bahan tersebut dicampur dan dicetak. Sedangkan untuk pembuatan mortar dengan penambahan abu ampas tebu, dengan menambahkan abu ampas tebu sebanyak 2, 4 dan $6 \%$ dari berat klinker. Kemudian bahan-bahan tersebut dicampur dan dicetak dengan menggunakan cetakan untuk mortar.

\section{Pembuatan mortar}

Dengan menimbang semen sebanyak $740 \mathrm{~g}$ dan pasir Ottawa sebanyak $2035 \mathrm{~g}$. Kemudian masukkan sejumlah air $(408 \mathrm{~mL})$ kedalam mixer. Wadah pasir pada mixer diisi dengan pasir Ottawa, dan semen kedalam mixer. Setelah itu tekan tombol "START AUTOMATIC". Adonan mortar tadi dimasukkan kedalam mould (cetakan untuk mortar) hingga berisi setengahnya. Lalu dengan menggunakan tamper (alat untuk menumbuk) ditumbuk sebanyak 32 kali. Kemudian ditambahkan lagi adonan mortar hingga mould penuh. Ditumbuk lagi dengan menggunakan tamper sebanyak 32 kali. Setelah itu kelebihan mortar dipotong dan diratakan permukaannya dan disimpan didalam ruang lembab \pm 24 jam. Mortar yang sudah mengeras dikeluarkan dari mould dan siap untuk dilakukan pengujian pada umur 3,7 dan 28 hari.

3. Proses pengujian kuat tekan

Pengujian kuat tekan mortar dilakukan pada saat mortar telah berumur 3, 7 dan 28 hari. Pengujian ini menggunakan alat yaitu Compressive Strenght. Cara kerja alat ini dengan menghidupkan tombol "ON" pada alat. Kemudian ditekan tombol "START" dan dipilih menu execute jenis benda uji yang akan diuji dan ditekan tombol "START" kembali. Untuk membuka pintu dan memasukkan benda uji ditekan titik (.) kemudian pintu ditutup kembali. Tobol "START" ditekan untuk untuk mengetahui nilai kuat tekan dari mortar.

4. Pengukuran $\mathrm{pH}$ air rendaman

Setiap dilakukan pengujian kuat tekan mortar, maka $\mathrm{pH}$ dari air rendaman diukur dengan menggunakan $\mathrm{pH}$ meter. Sebelum menggunakan alat $\mathrm{pH}$ meter terlebih dahulu dilakukan pengkalibrasian alat dengan menggunakan larutan buffer yang sesuai dengan kerja instruksi alat. Selanjutnya elektroda dibilas dengan menggunakan akuades dan keringkan dengan menggunakan tissu. Sebelum mencelupkan elektroda kedalam sampel (air rendaman) terlebih dahulu elektroda tersebut dibilas dengan sampel, kemudian baru elektroda tersebut dicelupkan kedalam sampel dan biarkan sampai $\mathrm{pH}$ meter menunjukkan pembacaan yang tetap. Angka yang muncul pada alat $\mathrm{pH}$ meter merupakan $\mathrm{pH}$ dari sampel.

5. Penentuan Total Zat Padat Terlarut (TDS) air rendaman mortar.

Metoda yang dilakukan untuk menentukan TDS pada air rendaman mortar adalah metoda gravimetri. Pengujian ini dilakukan pada air rendaman sebelum dan sesudah perendaman mortar. Prosedur kerjanya yaitu cawan penguap yang telah 
bersih dan dipanaskan didalam furnace pada suhu $550^{\circ} \mathrm{C}$ selama $1 \mathrm{jam}$, kemudian suhunya diturunkan menjadi $105^{\circ} \mathrm{C}$. cawan penguap tersebut didinginkan didalam desikator dan ditimbang. Sebanyak $25 \mathrm{~mL}$ air rendaman hasil saringan dari corong kaca masir dituang kedalam cawan penguap. Kemudian cawan yang berisi sampel dipanaskan kembali kedalam oven pada suhu $103-105^{\circ} \mathrm{C}$ sampai semua air menguap. Cawan tersebut didinginkan kembali didalam desikator dan ditimbang kembali sampai didapatkan bobot konstan.

6. Penentuan Kesadahan Total

Sebanyak $25 \mathrm{~mL}$ sampel (air rendaman) diuji secara duplo, dimasukkan kedalam erlenmeyer $250 \mathrm{~mL}$ dan diencerkan dengan akuades sampai volume larutan menjadi $50 \mathrm{~mL}$. Untuk air laut dilakukan pengenceran dalam labu ukur $250 \mathrm{~mL}$, kemudian diambil $25 \mathrm{~mL}$ masukkan kedalam Erlenmeyer $250 \mathrm{~mL}$. Ditambahkan $5 \mathrm{~mL}$ larutan buffer $\mathrm{pH} 10$ dan 2 tetes indikator EBT. Kemudian dititrasi dengan menggunakan larutan EDTA 0,02 M secara perlahan-lahan sampai terjadi perubahan warna merah keunguan menjadi biru. Volume pemakaian EDTA 0,02 M dicatat. Pengujian dilakukan 2 kali dan volumenya dirata-ratakan.

\section{HASIL DAN PEMBAHASAN}

1. Kuat Tekan

Setelah dilakukan pembuatan mortar dan direndam pada masing-masing air rendaman, yaitu akuades dan air laut. Kemudian dilakukan pengukuran kuat tekan dengan menggunakan alat Compresive Strenght yang dilakukan masing-masing pada 3, 7 dan 28 hari perendaman. Dari hasil pengujian kuat tekan mortar dengan penambahan abu ampas tebu yang direndam dalam akuades dan air laut dapat dilihat pada gambar dibawah ini:

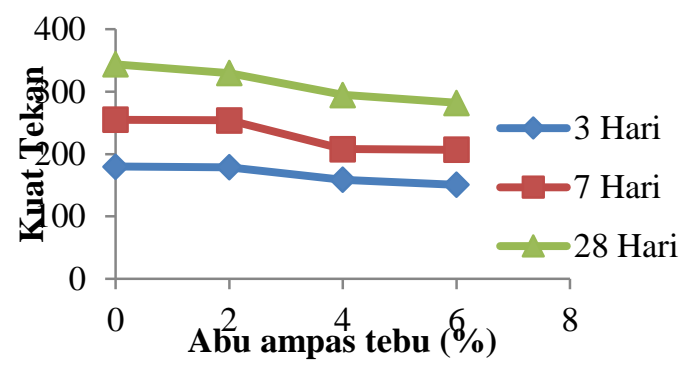

Gambar 1. Pengaruh penambahan abu ampas tebu terhadap kuat tekan pada perendaman akudes

Data yang diperoleh berdasarkan perhitungan statistik pada lampiran 6 dan 7, tidak terjadi perubahan kuat tekan secara signifikan pada perendaman 3,7 dan 28 hari dengan penambahan abu ampas tebu sampai 2\%. Akan tetapi dengan penambahan abu ampas tebu lebih dari $2 \%$ terjadi perubahan yang signifikan terjadi penurunan kuat tekan mortar. Sedangkan berdasarkan lamanya perendaman, terjadi peningkatan kuat tekan yang signifikan.

Secara umum dengan bertambahnya komposisi abu ampas tebu, maka kuat tekan mortar yang direndam dalam akuadest semakin lama semakin menurun. Dan dengan lamanya perendaman, maka kuat tekannya semakin lama semakin meningkat. Waktu berpengaruh terhadap senyawa C3A, dengan semakin lama waktu perendaman maka jumlah senyawa C3A juga akan semakin banyak sehingga proses pengerasan akan semakin lama dan berpengaruh pada kuat tekan mortar (Shariq, Prasad, \& Ahuja, 2007).

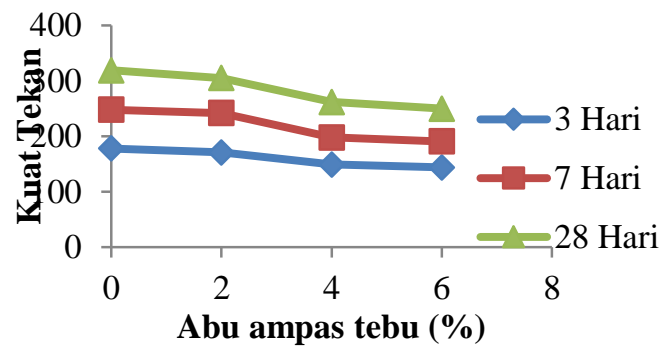

Gambar 3. Pengaruh penambahan abu ampas tebu terhadap kuat tekan pada perendaman air laut

Berdasarkan dari hasil perhitungan secara statistik pada lampiran 6 dan 7 , pada perendaman 3, 7 dan 28 hari tidak terjadi perubahan yang signifikan pada penambahan abu ampas tebu sampai $2 \%$. Selanjutnya dengan penambahan abu ampas tebu lebih dari $2 \%$ menyebabkan kuat tekan mortar semakin menurun. Penggunaan air laut dapat menyebabkan permukaan mortar akan berubah menjadi warna putih. Hal ini menunjukkan telah terjadi kerusakan pada mortar akibat pengaruh air laut. Kerusakan ini disebabkan adanya klorida yang terkandung di dalam air laut, yaitu $\mathrm{NaCl}$ dan $\mathrm{MgCl}_{2}$. Senyawa ini bila bertemu 
dengan senyawa semen akan menyebabkan gipsum dan kalsium sulphoaluminat dalam semen mudah larut (Utari, 2004).

Mortar yang direndam dalam akuades memiliki kuat tekan yang memenuhi SNI 15-7064-2004 pada lampiran 2, untuk semua variasi penambahan abu ampas tebu. Sedangkan untuk perendaman mortar dalam air laut, yang memenuhi SNI 15-7064-2004 pada variasi penambahan abu ampas tebu hanya $0 \%$ (untuk 3 hari $178 \mathrm{~kg} / \mathrm{cm}^{2}, 7$ hari $248 \mathrm{~kg} / \mathrm{cm}^{2}$, dan 28 hari $319 \mathrm{~kg} / \mathrm{cm}^{2}$ ) dan $2 \%$ (untuk 3 hari $171 \mathrm{~kg} / \mathrm{cm}^{2}, 7$ hari 242 $\mathrm{kg} / \mathrm{cm}^{2}$, dan 28 hari $305 \mathrm{~kg} / \mathrm{cm}^{2}$ ).

Ada beberapa hal yang menjadi penyebab rendahnya kuat tekan mortar dengan campuran abu ampas tebu ini, antara lain pengaruh ukuran partikel abu ampas tebu serta adanya pengotor berupa materi yang tidak terbakar sempurna yang terkandung dalam abu ampas tebu. Serta bahan-bahan organik juga menyebabkan turunya kekuatan mortar dengan penambahan abu ampas tebu. Secara umum pengaruh penambahan abu ampas tebu tidak mempengaruhi kuat tekan mortar semen PCC menurut SNI.

2. $\mathrm{pH}$ air rendaman

Pengukuran $\mathrm{pH}$ air rendaman mortar dilakukan sama pada hari pengukuran kuat tekan. Pengukuran $\mathrm{pH}$ air rendaman menggunakan alat $\mathrm{pH}$ meter yang telah dikalibrasi terlebih dahulu. Dari pengukuran $\mathrm{pH}$ air rendaman terhadap akuades dan air laut dapat dilihat pada gambar dibawah ini:

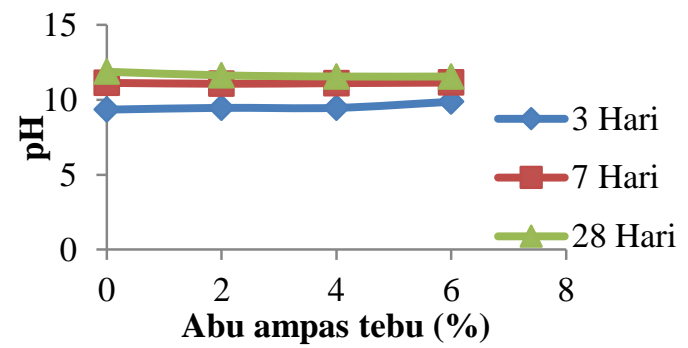

Gambar 4.Pengaruh penambahan abu ampas tebu terhadap $\mathrm{pH}$ pada perendaman akuades

Berdasarkan gambar diatas, pengaruh penambahan abu ampas tebu terhadap $\mathrm{pH}$ air rendaman mortar dalam akuades tidak memiliki pengaruh yang besar. Dimana pHnya naik dengan lamanya waktu perendaman mortar. Perhitungan secara statistik pada lampiran 6 dan 7, pada perendaman 3 hari tidak terjadi perubahan yang signifikan sampai penambahan abu ampas tebu $4 \%$ dan terjadi perubahan yang signifikan dengan penambahan lebih dari 4\%. Pada perendaman 7 hari tidak terjadi perubahan yang signifikan pada variasi penambahan abu ampas tebu. Sedangkan pada perendaman 28 hari terjadi perubahan yang signifikan pada penambahan abu ampas tebu lebih dari 2\%. Hal ini disebabkan karena kalsium oksida $(\mathrm{CaO})$ yang ada dalam semen bereaksi dengan air membentuk kalsium hidroksida $\left(\mathrm{Ca}(\mathrm{OH})_{2}\right)$ (Gunawan, 2000).

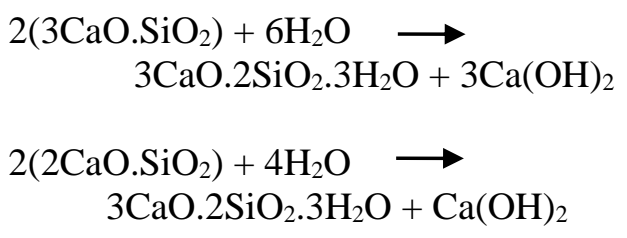

Terjadinya perubahan $\mathrm{pH}$ air rendaman mortar didalam akuades sangat tergantung kepada kelarutan logam-logam dari komposisi semen yang telah ditambahkan abu ampas tebu.

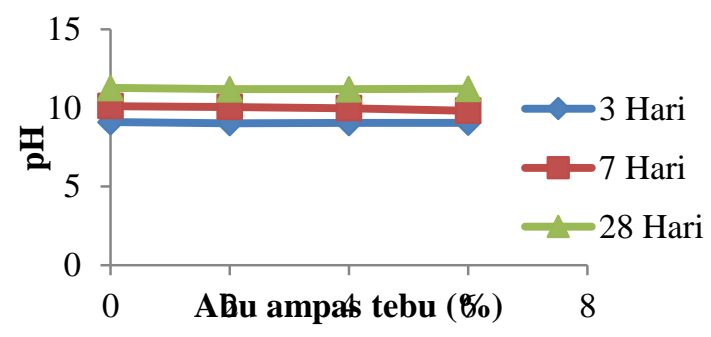

Gambar 5. Pengaruh penambahan abu ampas tebu terhadap $\mathrm{pH}$ pada perendaman air laut

Dari gambar diatas dapat dilihat berdasarkan perhitungan statistik pada lampiran 6 dan 7, secara umum tidak terjadi perubahan yang signifikan pada variasi penambahan abu ampas tebu dan lamanya waktu rendaman. Hal ini disebabkan karena kalsium oksida $(\mathrm{CaO})$ yang ada dalam semen bereaksi dengan air membentuk kalsium hidroksida $\left(\mathrm{Ca}(\mathrm{OH})_{2}\right)$. Kemudian kalsium hidroksida yang terdapat dalam mortar akan bereaksi secara perlahan dengan magnesium klorida $\left(\mathrm{MgCl}_{2}\right)$ yang ada dalam air laut sehingga menghasilkan magnesium hidroksida $\left(\mathrm{Mg}(\mathrm{OH})_{2}\right)$ dan kalsium klorida $\left(\mathrm{CaCl}_{2}\right)$ serta adanya logam-logam terlarut. Semakin lama perendaman mortar dalam air laut tersebut 
maka air laut akan bersifat basa sehingga menyebabkan $\mathrm{pH}$ air laut meningkat [7].

$\mathrm{CaO}+\mathrm{H}_{2} \mathrm{O} \longrightarrow \mathrm{Ca}(\mathrm{OH})_{2}$
$\mathrm{Ca}(\mathrm{OH})_{2}+\mathrm{MgCl}_{2} \rightarrow \mathrm{Mg}(\mathrm{OH})_{2}+\mathrm{CaCl}_{2}$

Apabila dibandingkan antara air rendaman mortar dalam akuades dan air laut, pengaruh $\mathrm{pH}$ yang besar terjadi pada perendaman air laut. Dimana $\mathrm{pH}$ air laut lebih tinggi dibandingkan dengan $\mathrm{pH}$ akuades. Dengan tingginya $\mathrm{pH}$ juga mengakibatkan kuat tekan mortar semakin lama semakin menurun.

\section{TDS ( Total Dissolve Solid / Total} Padatan Terlarut)

Pengujian TDS dilakukan pada air rendaman mortar dalam akuades. Untuk hasil pengujian TDS dapat dilihat pada gambar dibawah ini :

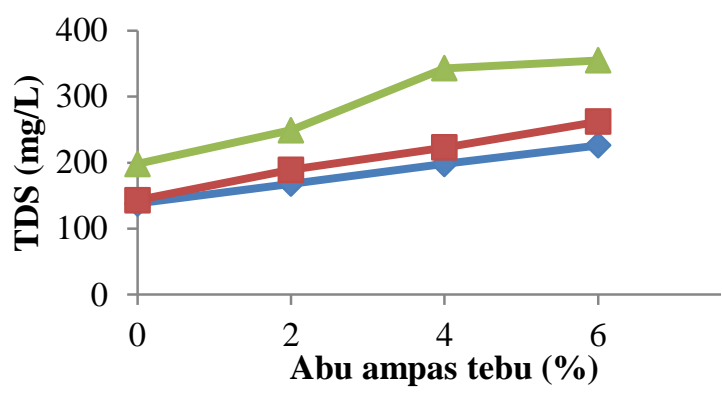

Gambar 6. Pengaruh penambahan abu ampas tebu terhadap TDS pada perendaman akuades

Pada gambar 6 dapat dilihat bahwa pengaruh penambahan abu ampas tebu terhadap jumlah TDS mengalami kenaikan. Begitu juga dengan lamanya perendaman mortar didalam akuades, menyebabkan jumlah TDSnya semakin lama semakin meningkat. Untuk penambahan abu ampas tebu sampai $6 \%$ pada perendaman 3 dan 7 hari tidak begitu jauh berbeda. Sedangkan pada perendaman 28 hari jumlah TDS mengalami peningkatan. Ini juga dibuktikan dengan terjadinya penurunan kuat tekan mortar dengan penambahan abu ampas tebu lebih dari $2 \%$, sehingga menyebabkan banyaknya logam-logam terlarut yang terdapat didalam air rendaman.

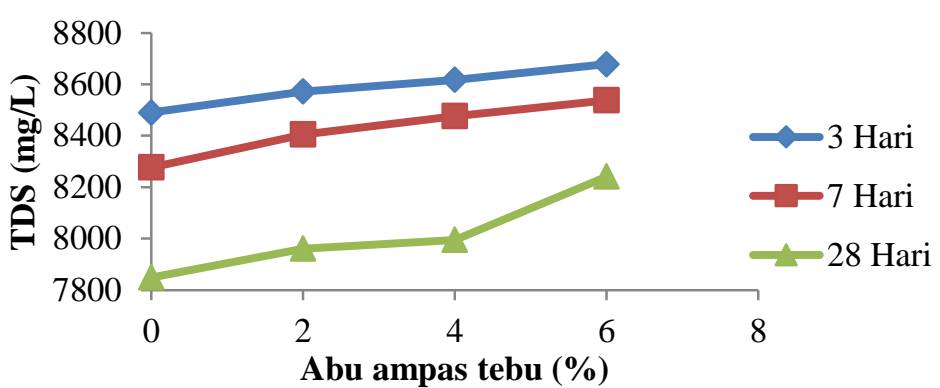

Gambar 7. Pengaruh penambahan abu ampas tebu terhadap TDS pada perendaman air laut

Pada gambar 7 dapat dilihat bahwa pengaruh penambahan abu ampas tebu pada mortar yang direndam dalam air laut terhadap jumlah TDS meningkat. Dan dengan lamanya perendaman maka jumlah TDSnya semakin lama semakin menurun. Dapat dilihat pada gambar, bahwa TDS pada perendaman 3 hari lebih besar dari pada perendaman 7 dan 28 hari. Hal ini disebabkan karena adanya logam-logam terlarut dan garam dalam air laut tersebut banyak yang menempel pada mortar, sehingga menyebabkan mortar mengalami perubahan warna dan kuat tekannya menurun dan jumlah TDSnya juga menurun.

Bila dibandingkan jumlah TDS antara akuades dan air laut, maka jumlah TDS air laut lebih besar daripada TDS akuades. TDS merupakan bahan-bahan terlarut dalam air yang tidak tersaring dengan kertas saring millipore dengan ukuran pori $0,45 \mu \mathrm{m}$. Padatan ini terdiri dari senyawa-senyawa anorganik dan organik yang terlarut dalam air, mineral dan garamgaramnya. Penyebab utama terjadinya TDS adalah bahan anorganik berupa ion-ion yang sering dijumpai di perairan.

\section{Kesadahan Total}

Pengujian kesadahan total dilakukan pada air rendaman mortar yaitu akuades dan air laut. Pengujian ini berdasarkan titrasi kompleksometri. Hasil pengujian dapat dilihat pada gambar dibawah ini : 


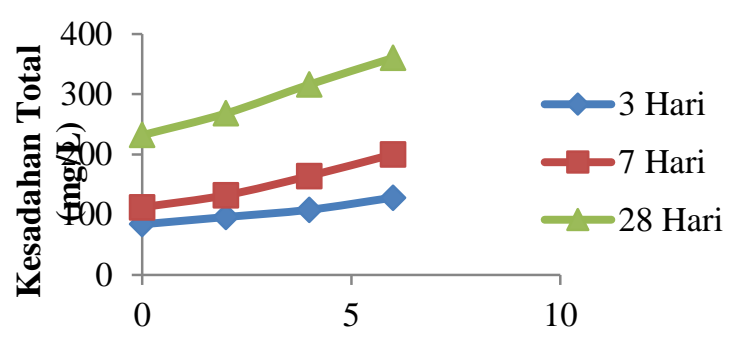

Abu ampas tebu (\%)

Gambar 8.Pengaruh penambahan abu ampas tebu terhadap kesadahan total pada perendaman akuades

Pada gambar 8 dapat dilihat bahwa pengaruh penambahan abu ampas tebu terhadap kesadahan total air rendaman akuades semakin lama semakin meningkat, dan pada lama perendaman dalam akuades jumlah kesadahan totalnya juga semakin meningkat. Tapi pada hari ke-28 dengan penambahan abu ampas tebu mulai 4 dan 6\% kesadahan totalnya mengalami kenaikan yang signifikan. Hal ini disebabkan karena adanya ion-ion yang larut dalam akuades. Dan karena adanya sebagian ion $\mathrm{Ca}^{2+}$ dan $\mathrm{Mg}^{2+}$ dari abu ampas tebu yang tidak menyatu dengan semen PCC dan terlarut dalam air rendaman. Dengan semakin lama perendaman maka semakin banyak ion-ion yang larut dalam akuades yang berasal dari mortar.

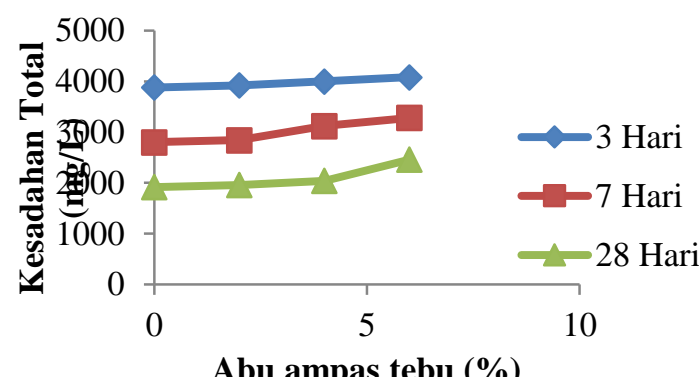

Gambar 9.Pengaruh penambahan abu ampas tebu terhadap kesadahan total pada perendaman air laut

Pada gambar 9 pengaruh penambahan komposisi abu ampas tebu terhadap kesadahan total air rendaman mortar dalam air laut mengalami kenaikan. Sedangkan dengan lamanya perendaman kesadahan total menjadi menurun dengan lamanya waktu perendaman. Pada grafik dapat dilihat bahwa, kesadahan pada perendaman 3 hari lebih besar bila dibandingkan dengan perendaman mortar pada 7 dan 28 hari. Ini berbanding terbalik dengan perendaman dalam akuades. Hal ini disebabkan karena adanya interaksi sebagian ion $\mathrm{Ca}^{2+}$ dan ion $\mathrm{Mg}^{2+}$ yang terlarut yang berasal dari abu ampas tebu dan air laut masuk kedalam pori-pori mortar dan menyatu dalam komposisi kimia semen.

\section{KESIMPULAN}

Dengan adanya penambahan abu ampas tebu pada pembuatan semen PCC, menyebabkan kuat tekan mortar semakin menurun tetapi masih memenuhi SNI 157064-2004 semen PCC.Pengaruh penambahan abu ampas tebu pada perendaman air laut menurunkan kuat tekan. Kuat tekan mortar akan mengalami penurunan dengan penambahan abu ampas tebu lebih dari $2 \%$.Makin lama dilakukan perendaman mortar menyebabkan $\mathrm{pH}$ air rendaman semakin naik.Semakin lama perendaman mortar nilai TDS dan kesadahan total air rendaman mortar pada akuades semakin meningkat, sedangkan pada perendaman air laut dengan lamanya perendaman nilai TDS dan kesadahan total menjadi menurun. Abu ampas tebu dapat digunakan sebagai alternatif lain untuk mengurangi penggunaan klinker pada pembuatan semen PCC dan sebagai pemanfaatan limbah.

\section{DAFTAR RUJUKAN}

Anggraini, Retno, Herlin Indrawahyuni. (2009). Pengaruh Variasi campuran dan Lama Perendaman Spesi dalam Air Laut terhadap Kuat Tekan dan Kedalaman Instrusinya. Malang : Universitas Brawijaya.

Gunawan. (2000). KonstruksiBeton I. Jakarta : Delta Teknik Group.

Mulyati, Sri, Dahyunir Dahlan dan Elvis Adris. ( - ). Pengaruh Panen Massa Hasil Pembakaran Serbuk Kayu dan Ampas Tebu Pada Mortar Terhadap Sifat Mekanik dan Sifat Fisisnya. Artikel FMIPA. UNAND.

Margaretta, Krisna. (2009). Pemanfaatan Ampas Tebu Sebagai Bahan Baku Dalam Pembuatan Papan Partikel. Skripsi Departemen Teknologi Pertanian. Fakultas Pertanian. Universitas Sumatera Utara.

Nugraha, Paulus. (2003). Bahan Ajar Teknologi Beton. Medan : 
Laboratorium Bahan Rekayasa Teknik Sipil USU.

Shariq, m, Prasad, j \& Ahuja,a.k. (2007). Strenght Development of Cement Mortar and Concrete Incoorporating GGBFS. Depatrment of Civil Engineering IITRoorkee, India.

Utari. (2004). Efek Air Laut Terhadap Kekuatan Beton Lateks-Emulsion. Jurnal Aksial. Khatulistiani,Vol. 6, No. 1. Hal. 38-46, April 2004. 